\title{
COMPRESSION WOOD IN Pinus radiata II: DENSITY AND CHEMICAL COMPOSITION
}

\section{MADERA DE COMPRESIÓN EN Pinus radiata II: DENSIDAD Y COMPUESTOS QUÍMICOS}

\author{
Diaz-vaz, J. E. ${ }^{1}$; Ananías, R.A. ${ }^{2}$; Rodríguez, S. ${ }^{3}$; Torres, M. ${ }^{1}$; Fernández, A..$^{1}$; Poblete, H. ${ }^{1}$
}

\begin{abstract}
Ten 22 year old radiata pine trees growing in two stands in Chile, one in clay and the other in humid sand soils showing some lean, were assessed for chemical composition and wood density of compression wood.

Significant differences in type of wood in density $\left(33 \mathrm{~kg} / \mathrm{m}^{3}\right)$, lignin $(1.944 \%)$, alpha-cellulose $(-2.634 \%)$, ethanol toluene extractives $(0.567 \%)$ and pentose $(0.742 \%)$ were found between matched sample of compression and opposite woods.

Differences in juvenile and mature wood were significant for both density $\left(-4 \mathrm{~kg} / \mathrm{m}^{3}\right)$ and pentose $(1.628 \%)$, and site differences were found for wood density $\left(28 \mathrm{~kg} / \mathrm{m}^{3}\right)$, extractives $(0.978 \%)$ and apparent for alpha cellulose (1.223\%).

In comparison with other studies, our results suggested that the compression wood formed from trees with light visible lean corresponded to a mild compression class.
\end{abstract}

Keywords: Compression wood, radiata pine, basic density, lignin, holocellulose, alpha-cellulose, pentose, ethanol-toluene, ash

\section{RESUMEN}

Se analizó la madera de compresión en diez árboles de 22 años de edad de Pinus radiata D Don creciendo en dos sitios en Chile, uno en suelo de arena húmeda y el otro en suelo arcilloso. Singularidades de la madera de compresión y madera opuesta se compararon en estos árboles con inclinaciones menores a $10^{\circ}$ y excentricidades reducidas.

Diferencias significativas se registraron entre madera de compresión y opuesta en los valores registrados para la densidad básica de $33\left(\mathrm{~kg} / \mathrm{m}^{3}\right)$, en proporción de lignina de $1.944(\%)$, en alfa-celulosa de $-2.634(\%)$, en pentosanos de $0.742(\%)$ y en extraíbles en etanol-tolueno de 0.978 (\%) y aparentemente diferente en el caso de alfa celulosa en $1.223(\%)$.

Las diferencias entre madera juvenil y madera madura fueron significativas en los casos de la densidad de $-4\left(\mathrm{~kg} / \mathrm{m}^{3}\right)$ y en pentosanos en $1.628(\%)$, y diferencias entre los dos sitios para los casos de la densidad con $28\left(\mathrm{~kg} / \mathrm{m}^{3}\right)$, en extractivos con $0.978(\%)$ y diferencias moderadas en alfa celulosa con $1.223(\%)$.

\footnotetext{
${ }^{1}$ Instituto de Tecnología de Productos Forestales, Facultad de Ciencias Forestales.

Universidad Austral de Chile. Valdivia, Chile.

${ }^{2}$ Departamento de Ingeniería en Maderas. Facultad de Ingeniería. Universidad del Bío-Bío. Concepción, Chile. ananias@ubiobio.cl

${ }^{3}$ Inger S.A. Chiguayante, Chile. s_rodríguez@ingerquimica.com

Corresponding author: jdiazvaz@uach.cl

Received: 27.10 2008. Accepted: 23.072009
} 
Las diferencias y coincidencias de estos resultados con los de otros autores se han considerado para estimar que la madera de compresión formada por estos árboles, con inclinaciones reducidas, correspondería al tipo de madera de compresión leve.

Palabras claves: Madera de compresión, pino radiata, densidad básica, lignina, holocelulosa, alfacelulosa, pentosano, etanol-tolueno, cenizas

\section{INTRODUCTION}

Most of the physical, mechanical and chemical properties of wood can change with the presence of compression wood. In general, this feature is related to leaning or swept trees (Timell 1986). The trees' loss of verticality is associated to a variation in the hormonal levels in the cambium forming the compression wood. In addition, trees without lean or with smaller deviations can also contain compression wood (Shelbourne et al. 1969, Warensjö and Rune 2004, Timell 1986).

Numerous investigations analyze the particularities of compression wood $(\mathrm{CW})$, them with those of opposite wood (OW) and wood from trees without $\mathrm{CW}$. They include differences such as: greater proportion of lignin, lack of the $\mathrm{S}_{3}$ wall, presence of helical checks, higher microfibril angle in the $\mathrm{S}_{2}$ wall, rounded tracheid sections, presence of intercellular spaces (Takabe et al. 1992; Donaldson et al. 2004), reduction of the lignin proportion in the middle lamella and concentration of lignin between $S_{1}$ and $S_{2}$ (Donaldson et al 2004), shorter tracheids (Nicholls 1982; Diaz-vaz et al. 2007), higher width of the cell wall in the intermediate and latewood, wider rings, darker coloration and higher longitudinal skrinkage than those of OW or wood from trees without CW (Harris 1977). The growth eccentricity is also a singularity observed in most trees with CW (Nicholls 1982).

Anatomical, physical and chemical characteristics of $\mathrm{CW}$ are associated to unsuitable properties for many of the products made from this wood, for example: pulp and paper (Timell 1982; Ban et al. 2004), fiber board's (Akbulut and Ayrilmis 2006), and particle boards (Roffael et al. 2005). They affect wood permeability, the drying process (Davis et al. 2002), the quality of the sawn lumber and its derived products (du Torr 1963; Donaldson and Turner 2001),

Larger or smaller deviations from vertical of the stems can originate severe to mild degrees of CW, including the zone known as OW corresponding to the one in the opposite side of CW (Harris 1977, Donaldson et al. 2004, Diaz-vaz et al. 2007). On the other hand, OW does not share CW characteristics and it only shows smaller differences with the wood from trees without CW.

The relationship between wood stem lean and the presence of $\mathrm{CW}$ can be different when severe CW can be distinguished from mild CW (Nicholls 1982). In the case of relatively straight and vertical Pinus radiata trees, mild CW is quite frequent (Nicholls 1982). For straight and leaning trees the growth eccentricity has been established as a good index to recognize the presence of mild CW (Nicholls 1982).

Similar density values could be attributed to cellular diameters from slightly lean trees CW and OW that were not statistically different (Spicer and Gartner 1998, Donaldson et al. 2004, Diaz-vaz et al. 2007). Other studies showed differences in the cell diameters between CW and OW (Spicer and Gartner 1998, Mayr and Cochard 2003). These discordant results can be partly attributed to the different $\mathrm{CW}$ degrees, from severe to mild, and also to the differences in the wood formation stage, that is, differences on either earlywood or latewood (Donaldson et al. 2004, Diaz-vaz et al. 2007). Thus, the exerted genetic control on Pinus sylvestris diameters of radial and tangential lumens was strong in the case of earlywood, moderate in the case of latewood and low for the width of the cell wall (Hannrup et al. 2001). 
A study of Pinus radiata in New Zealand showed that outer wood density from many of the regional means would be highly significantly statistical difference (Cown et al. 1991). Reduced density differences between sites have been reported in Pinus radiata wood in Australia (Raymond and Joe 2007). On the other hand in Chile, differences in density between sites were found in non-compression wood, juvenile, intermediate and mature woods (Delmastro et al. 1982). In the case of severe CW, differences in the amount of CW between sites can be expected (Burdon 1975). In other species, as summarized by Zobel et al. (1960) the effect of the environment on the density often provides confused and contradictory results.

The features of $\mathrm{CW}$ depend on the severity degree. The mild forms of $\mathrm{CW}$, unlike severe $\mathrm{CW}$, show minor differences with the OW in terms of: presence of intercellular spaces, cellular dimensions, density of the wood and microfibril angle. In the case of the Pinus radiata juvenile wood, a reduced lignin concentration is associated to this wood in the external part of the secondary wall $\mathrm{S}_{2}$ (Donaldson et al. 2004). The change in the arrangement of microfibril in the helicoidal thickenings in Taxus cuspidate is reported as an indication of CW formation (Donaldson et al. 2004; Yoshizawa, et al. 1992). In addition, beta-1-4-galactan synthesis has also been interpreted as the first physiological reaction in the formation of CW in Picea sitchensis wood (Altaner et al.2007). In terms of the variation in the lignin concentration, it reaches its maximum increase in the case of severe CW. The CW lignin content was significantly higher than in OW and agrees with most studies on this matter. CW had more lignin and galactose but less cellulose and mannose (Timell 1982). The greater amount of lignin in CW resulted from the abundance of precursors available in the zones during the differentiation process (Bland 1958). Nevertheless, these differences were not always evident. It is worth remembering that the proportion of lignin is not the same within the cell wall, that the $\mathrm{CW}$ middle lamella is less lignified however, the secondary wall $\mathrm{S}_{1}$ and the $\mathrm{S}_{2}$ duplicate the values found in OW. In the case of mild CW found in the first rings of juvenile wood there is a reduction of lignin in the corners of the cells. This would be the first change indicating the formation of CW (Donaldson et al. 2004). A lignin increase in the external part of the secondary wall $\mathrm{S}_{2}$, known as $\mathrm{S}_{2}(\mathrm{~L})$, is a difference in the distribution of the lignin present in the corners of the CW cells (Timell 1982, Donaldson et al.2004).

In Pinus taeda wood, the alpha-cellulose content does not seem to adjust to any climatic or edaphic zone (Zobel et al. 1960). Despite the fact that it was likely to expect an increase in alpha-cellulose from the pith to growth ring 15 and a further more or less constant value (Harwood 1971, Uprichard 1971).

The variability of the CW characteristics can be increased depending whether it is in juvenile or mature wood. This occurs in trees with smaller inclinations which seem to have a higher proportion of mild CW (Timell 1986).

Bearing in mind that most of the trees in Pinus radiata plantations generally have straight stems with little sweep or lean, we identified and analyzed the features of CW and compared them with the OW properties of juvenile and mature wood of slightly sweep matches from three height levels collected from each tree. The analysis considered the physical and chemical characteristics of $\mathrm{CW}$ and the respective OW. All these analyses took place in trees with small stem deviations belonging to two Pinus radiata stands, growing in different sites.

In the present study we describe physical and chemical characteristics on CW present in Pinus radiata tree with smaller leaning, and how some of these properties were relate to mild $\mathrm{CW}$. In this way, this research is concerning with the Pinus radiata $\mathrm{CW}$ characterization as a basis for improving the pulp and paper productivity. 


\section{MATERIAL AND METHOD}

The study was carried out on ten Pinus radiata trees from two 22 years old stands, five of them growing in humid sand flat soil $\left(37^{\circ} 20^{\prime} \mathrm{S}-71^{\circ} 30^{\prime} \mathrm{W}\right)$ and the other five in clay flat soil $\left(37^{\circ} 30^{\prime} \mathrm{S}\right.$ $72^{\circ} 30^{\prime} \mathrm{W}$ ), in Chile. The chosen trees included those with straight stems, defects-free wood and the absence of lean higher than $10^{\circ}$ with respect to the vertical line. Disks at three height levels were collected from each tree. The lower disks were cut at HB and those from the second and third heights were taken centered in the respective third, that is, between the $\mathrm{BH}$ and a $10 \mathrm{~cm}$ height commercial diameter (see figure 1).

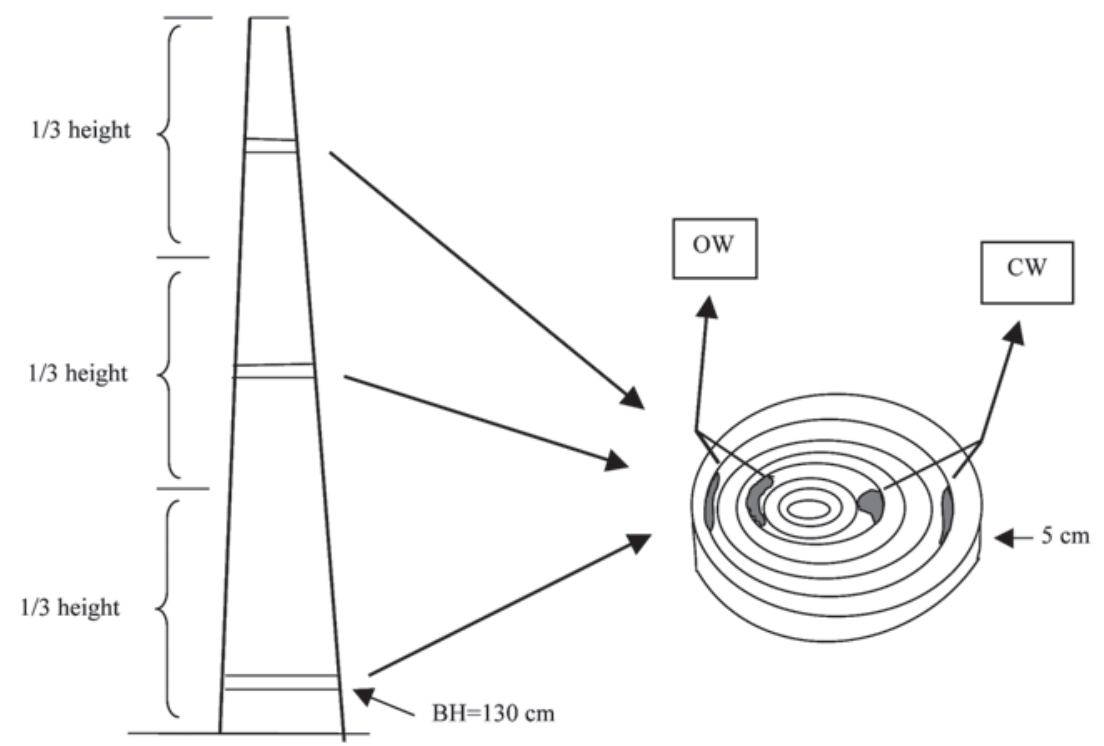

Figure 1. Disks at three height levels collected trom each tree. Similar amounts of opposite wood and compression wood sampled from each disk.

On the disks' polished surfaces, the zones of $\mathrm{CW}$ and $\mathrm{OW}$ were visually identified. Compression wood was identified by means of: the eccentricity of the pith, the ring width, the reddish color present in this type of wood and the similar latewood appearance shown by part of earlywood.

Similar amounts with the same wood age of OW and CW were sampled from each disk. Thus, both types of wood participated in a similar proportion and with comparable ring ages in all the tests. The samples used to determine basic density and chemical compounds, corresponded to OW and CW extracted from the juvenile (first ten tree rings) and mature wood of each disk. Juvenile wood was considered the one between the pith and the tenth growth ring (Rivas 1982).

Bromecresol green indicator was used to distinguish the heartwood from sapwood (Diaz-vaz 1985). The heartwood diameter show values between $11,8 \%$ and $43,7 \%$. Nine from 30 disks did not have heartwood.

The basic density (not extractive free) was calculated after that oven-dry weight and the green volume by water displacement were obtained (Haygreen and Bowyer 1996). The chemical composition was determined for the pool of the trees sampled in each site, using the following norms: extractives (TAPPI 1988a); lignin (TAPPI 1988b); alpha cellulose (ASTM 1984), pentose (TAPPI 1984), ethanol toluene extractives (TAPPI 1988c), holocellulose (Poljack) (Haas et al. 1955) and ash (TAPPI 1985)). Table 1 shows the experimental design: 
Table 1. Trees, discs, soils and properties investigated in radiata pine compression and opposite wood

\begin{tabular}{|lr|l|}
\hline Properties & $=7$ & $\begin{array}{l}\text { Wood density, lignin, alpha-celulose, pentosan, ethanol-toluene, } \\
\text { holocelulose and ash. }\end{array}$ \\
\hline Soil type & $=2$ & Humid sand $\left(37^{\circ} 20^{\prime} \mathrm{S}-71^{\circ} 30^{\prime} \mathrm{W}\right)$, clay $\left(37^{\circ} 30^{\prime} \mathrm{S}-72^{\circ} 30^{\prime} \mathrm{W}\right)$. \\
\hline Wood age. $\quad=2$ & $\begin{array}{l}\text { Juvenile wood (from pith to growth ring 10), mature wood (from } \\
\text { growth rings } 11 \text { to bark). }\end{array}$ \\
\hline Stem height. $=3$ & DBH (1,3 m), second height, third height. \\
\hline Wood type. $=2$ & Compression wood, opposite wood (same growth rings). \\
\hline Number of trees $=5$ & Five trees per site. \\
\hline
\end{tabular}

Statistical normality of all registered values was tested with chi-square and Shapiro-Wilks and the variance homogeneity was confirmed by the Bartlett test (Morales 2005). No data transformations were necessary because data showed normal distributions and homogeneous variances. Basic density, lignin, holocellulose, alpha-cellulose, pentose, ethanol-toluene extractives and ash contents from CW and OW, were compared. Data from mature and juvenile woods from both site, were independently considered.

\section{RESULTS}

The growth eccentricity data confirmed the slight lean shown by the trees from both sites. Eccentricity values between $3.4 \%$ and $17.9 \%$ were calculated with the relation between average radii and the minor radii of the pieces. Trees from the humid sand and clay sites showed $9.5 \%$ and $12.5 \%$ average eccentricity, respectively.

Table 2 shows the variation of wood density of CW and OW for juvenile-wood and mature wood of the two stands at the different heights. It can be characterized by a decreasing density pattern in clay site; however the inverse is true for juvenile wood in humid sand site.

Table 2. Wood density, compression and opposite wood $\left(\mathrm{kg} / \mathrm{m}^{3}\right)$. Juvenile and mature wood of the two stands.

\begin{tabular}{|c|c|c|c|c|}
\cline { 2 - 5 } \multicolumn{1}{c|}{} & \multicolumn{4}{c|}{ Wood density $\left(\mathrm{kg} / \mathrm{m}^{3}\right)$} \\
\cline { 2 - 5 } \multicolumn{1}{c|}{ Clay site } & Humid sand site \\
\hline Stem height & OW & CW & OW & CW \\
\hline \multicolumn{5}{|c|}{ Juvenile wood } \\
\hline HD & 400 & 416 & 330 & 361 \\
\hline $2^{\circ}$ & 369 & 407 & 340 & 372 \\
\hline $3^{\circ}$ & 363 & 389 & 365 & 385 \\
\hline \multicolumn{5}{|c|}{ Mature wood } \\
\hline HD & 437 & 480 & 378 & 420 \\
\hline $2^{\circ}$ & 369 & 400 & nd & nd \\
\hline & \multicolumn{5}{|c|}{ nd = not determined } \\
\hline
\end{tabular}


The Student's t-test showed that the recorded wood density differences were all statistically significant (Table 3 ). The p-value less than 0.05 showed statistically significant effects that can be attributed to factors such as site (clay and humid sand), wood age (juvenile and mature wood), and type of wood (CW and $\mathrm{OW}$ ).

Table 3. Student's t-test for wood density $\left(\mathrm{kg} / \mathrm{m}^{3}\right)$. Differences in site (clay and humid sand), wood age (juvenile and mature wood), and type of wood (CW and OW) $\mathrm{p}=0.05$

\begin{tabular}{|c|c|c|c|c|c|}
\hline WOOD DENSITY & Mean & Std. Dev & Valid n & df & $\mathbf{P}$ \\
\hline Compression Wood & 405 & 46 & 46 & 90 & 0.0005 \\
\hline Opposite Wood & 372 & 45 & 46 & & \\
\hline Juvenile wood & 375 & 39 & 60 & 90 & 0.0004 \\
\hline Mature wood & 415 & 54 & 32 & & \\
\hline Clay site & 403 & 45 & 50 & 90 & 0.0007 \\
\hline Humid sand site & 375 & 46 & 42 & & \\
\hline $\begin{array}{l}\text { Clay site. Juvenile wood } \\
\text { CW } \\
\text { OW }\end{array}$ & $\begin{array}{l}404 \\
377\end{array}$ & $\begin{array}{l}27 \\
35\end{array}$ & $\begin{array}{l}15 \\
15\end{array}$ & 28 & 0.014 \\
\hline $\begin{array}{l}\text { Clay site. Mature wood } \\
\mathrm{CW} \\
\mathrm{OW}\end{array}$ & $\begin{array}{l}440 \\
403\end{array}$ & $\begin{array}{l}54 \\
52\end{array}$ & $\begin{array}{l}10 \\
10\end{array}$ & 18 & 0.066 \\
\hline $\begin{array}{l}\text { Humid sand. Juvenile wood } \\
\text { CW } \\
\text { OW }\end{array}$ & $\begin{array}{l}373 \\
345\end{array}$ & $\begin{array}{l}37 \\
34\end{array}$ & $\begin{array}{l}15 \\
15\end{array}$ & 28 & 0.020 \\
\hline $\begin{array}{l}\text { Humid sand. Mature wood } \\
\text { CW } \\
\text { OW }\end{array}$ & $\begin{array}{l}429 \\
378\end{array}$ & $\begin{array}{l}47 \\
49\end{array}$ & $\begin{array}{l}6 \\
6\end{array}$ & 10 & 0.048 \\
\hline $\begin{array}{l}\text { Clay site. CW } \\
\text { Juvenile wood } \\
\text { Mature wood }\end{array}$ & $\begin{array}{l}404 \\
440\end{array}$ & $\begin{array}{l}27 \\
35 \\
\end{array}$ & $\begin{array}{l}15 \\
10\end{array}$ & 23 & 0.016 \\
\hline $\begin{array}{l}\text { Clay site. OW } \\
\text { Juvenile wood } \\
\text { Mature wood }\end{array}$ & $\begin{array}{l}378 \\
403\end{array}$ & $\begin{array}{l}49 \\
52\end{array}$ & $\begin{array}{l}15 \\
10\end{array}$ & 23 & 0.074 \\
\hline $\begin{array}{l}\text { Humid sand. CW } \\
\text { Juvenile wood } \\
\text { Mature wood }\end{array}$ & $\begin{array}{l}373 \\
429\end{array}$ & $\begin{array}{l}37 \\
47\end{array}$ & $\begin{array}{c}15 \\
6\end{array}$ & 19 & 0.004 \\
\hline $\begin{array}{l}\text { Humid sand. OW } \\
\text { Juvenile wood } \\
\text { Mature wood }\end{array}$ & $\begin{array}{l}345 \\
378\end{array}$ & $\begin{array}{l}54 \\
49\end{array}$ & $\begin{array}{c}15 \\
6\end{array}$ & 19 & 0.046 \\
\hline
\end{tabular}

The results for the chemical components: lignin, alpha-cellulose, pentose and ethanol-toluene extractives, holocellulose and ash, showed results for site, type of wood and wood cambial age on the following Table 4. 
Tabla 4. Student's t-test for percentage of lignin, alpha cellulose, pentose, ethanol-toluene extractives, holocellulose and ash. Effect of: sites (clay and humid sand), type of wood (compression- opposite) and wood age (juvenile- mature). $\mathrm{p}=0.05$

\begin{tabular}{|c|c|c|c|c|c|}
\hline LIGNIN & Mean & Std. Dev & Valid n & df & $\mathrm{p}$ \\
\hline Compression Wood & 27.8 & 1.6 & 9 & 16 & 0.0045 \\
\hline Opposite Wood & 25.9 & 1.1 & 9 & & \\
\hline Juvenile wood & 27.2 & 1.4 & 12 & 16 & 0.1326 \\
\hline Mature wood & 26.2 & 2.1 & 6 & & \\
\hline Clay site & 26.7 & 1.7 & 10 & 16 & 0.2821 \\
\hline Humid sand site & 27.1 & 1.7 & 8 & & \\
\hline \multicolumn{6}{|c|}{ ALPHA CELULLOSE } \\
\hline Compression Wood & 43.2 & 2.7 & 9 & 16 & 0.0190 \\
\hline Opposite Wood & 45.8 & 2.3 & 9 & & \\
\hline Juvenile wood & 43.8 & 2.4 & 12 & 16 & 0.0589 \\
\hline Mature wood & 46.0 & 3.1 & 6 & & \\
\hline Clay site & 45.4 & 2.9 & 10 & 16 & 0.0609 \\
\hline Humid sand site & 43.4 & 2.2 & 8 & & \\
\hline \multicolumn{6}{|l|}{ PENTOSE } \\
\hline Compression Wood & 9.9 & 1.0 & 9 & 16 & 0.0737 \\
\hline Opposite Wood & 9.1 & 1.1 & 9 & & \\
\hline Juvenile wood & 10.0 & 0.7 & 12 & 16 & 0.0003 \\
\hline Mature wood & 8.4 & 0.8 & 6 & & \\
\hline Clay site & 9.8 & 1.2 & 10 & 16 & 0.1281 \\
\hline Humid sand site & 9.2 & 0.8 & 8 & & \\
\hline \multicolumn{6}{|c|}{ ETHANOL- TOLUENE } \\
\hline Compression Wood & 1.8 & 0.9 & 9 & 16 & 0.0524 \\
\hline Opposite Wood & 1.2 & 0.5 & 9 & & \\
\hline Juvenile wood & 1.5 & 0.8 & 12 & 16 & 0.4656 \\
\hline Mature wood & 1.5 & 0.6 & 6 & & \\
\hline Clay site & 1.9 & 0.7 & 10 & 16 & 0.0010 \\
\hline Humid sand site & 1.0 & 0.3 & 8 & & \\
\hline \multicolumn{6}{|c|}{ HOLOCELULLOSE } \\
\hline Compression Wood & 67.4 & 2.5 & 9 & 16 & 0.1077 \\
\hline Opposite Wood & 68.8 & 2.2 & 9 & & \\
\hline Juvenile wood & 68.0 & 2.2 & 12 & 16 & 0.4009 \\
\hline Mature wood & 68.0 & 2.9 & 6 & & \\
\hline Clay site & 67.6 & 2.6 & 10 & 16 & 0.1466 \\
\hline Humid sand site & 68.8 & 2.1 & 8 & & \\
\hline \multicolumn{6}{|l|}{ ASH } \\
\hline Compression Wood & 0.3 & 0.1 & 9 & 16 & 0.3676 \\
\hline Opposite Wood & 0.3 & 0.1 & 9 & & \\
\hline Juvenile wood & 0.3 & 0.0 & 12 & 16 & 0.2905 \\
\hline Mature wood & 0.3 & 0.1 & 6 & & \\
\hline Clay site & 0.3 & 0.1 & 10 & 16 & 0.3235 \\
\hline Humid sand site & 0.3 & 0.0 & 8 & & \\
\hline
\end{tabular}

The samples studied had a higher significant percentage of lignin in CW than in OW. The alphacellulose contents in OW were significant higher than those in the CW. Mature wood and clay site shows differences apparent significant than those in juvenile and humid sand site, respectively. The pentose content in mature woods was significant smaller than juvenile wood. The pentose in CW was apparent higher than OW. The ethanol-toluene extractives content were significant higher for clay site than humid sand site. Extractives content were higher in CW than in OW (Table 4).

In the case of holocellulose the differences were not significant ( $>>0.05)$ when comparing CW with OW. The holocellulose differences in type of wood and type site were not significant. The same results were obtained for ash (Table 4). 


\section{DISCUSSION}

In the present study slightly leaning trees had eccentricities of $3.4 \%$ to $17.9 \%$. For this reason it was expected to have mild CW and smaller differences when comparing them with $\mathrm{OW}$, based on the fact that differences between mild $\mathrm{CW}$ and $\mathrm{OW}$ can be smaller than those observed between severe CW and OW. In some cases mild CW and OW can have similar characteristics (Donaldson et al. 2004, Shelbourne and Ritchie 1968, Burdon 1975, Nicholls 1982).

\section{Wood Density}

The results of this study showed higher density in CW than in OW in leaning and reduced eccentricity trees (Tables 2 and 3). CW would be mild considering the reduced density increases between $4.7 \%$ and $24.3 \%$. These results agree with some reports and differ from others. Some studies have reported similar densities between mild CW and OW as well as higher densities in mild CW in relation to $\mathrm{OW}$ (Donaldson et al. 2004, Nicholls 1982).

As shown in Table 2 in both sites, the density of $\mathrm{CW}$ was higher than that of $\mathrm{OW}$ in the juvenile wood and mature wood at all heights. In juvenile wood, CW and OW shows high density at the lower portions of the tree (HB) in clay site but the density increases with height stem in humid sand site. Also was observed that the density in clay site was higher than that of the humid sand site. These results suggest that $\mathrm{CW}$ in juvenile wood was more frequently along the stem of the trees growing on poorer quality sites. So these results may be interest for log selection and also for improving the productivity to both sawmills and pulp mills.

The CW density is generally much higher than in normal wood. Nevertheless, results indicating similar values or bigger and lower differences between $\mathrm{CW}$ and $\mathrm{OW}$ can be associated to different causes. The smaller density of lignin in comparison with those of cellulose and hemicellulose and the greater proportion of lignin in the $\mathrm{CW}$ would be the cause of a smaller $\mathrm{CW}$ density. On the contrary, the greater proportion of intermediate and latewood in the $\mathrm{CW}$ rings can explain the higher $\mathrm{CW}$ density. Therefore, it is possible to assume that the cellular dimensions of earlywood and latewood are associated at different extent to the wood's phenotypic characteristics such as pith eccentricity. In consequence, major or minor density differences between $\mathrm{CW}$ and $\mathrm{OW}$ can be inferred from whether the $\mathrm{CW}$ is in the earlywood or the latewood. In this last growth zone is where CW mainly appears. Discrepancies in the density results of CW and OW can also be explained from anatomical differences (Spicer and Gartner 1998, Hannrup et al. 2001, Mayr and Cochard 2003, Donaldson et al. 2004, Diaz-vaz et al. 2007).

The student's t-test showed that in the present study site type of wood and wood age could affect the comparisons between CW and OW these two types of wood. However, the recorded density differences were all statistically significant (Table 3 ). The P-value less than 0.05 showed statistically significant effects that can be attributed to factors such as site (clay and humid sand), age (juvenile and mature wood), and type of wood (CW and OW), at 95\% confidence level.

Wood age (juvenile and mature) significantly affected the $\mathrm{CW}$ density (Table 3 ). The highest values were obtained for mature wood support the estimations showing more $\mathrm{CW}$ in external rings compared with the internal ones in Pinus radiata (Harris 1977, Nicholls 1982).

The site has a significant effect on the wood density values, the density values were higher $(30 \mathrm{~kg} /$ $\mathrm{m}^{3}$ ) in the clay site (Table 3 ). These different tendencies agree with the inter sites' wood density information. 


\section{Chemical Compounds}

The differences between CW and OW were significant for lignin, alpha-cellulose and in ethanoltoluene extractives. The differences in holocellulose and ash between $\mathrm{CW}$ and $\mathrm{OW}$, were not significant. The differences in pentose were apparent with $\mathrm{p}=0.074$ ( Table 4).

The differences in the lignin proportion between CW and OW obtained in the present study were reduced only $1.944 \%$ higher in CW. This result differs from those reported by Timell (1982) that show that $\mathrm{CW}$ has between 30 to $40 \%$ more of lignin than the wood from trees without $\mathrm{CW}$. The reduced differences found between $\mathrm{CW}$ and $\mathrm{OW}$ can be explained considering that in straight and slightly lean trees the greater proportion of the $\mathrm{CW}$ corresponds to mild $\mathrm{CW}$ which should have minor differences than those shown in the case of severe CW. On the other hand, non significant differences in lignin content were determined between juvenile and mature wood (Table 4). This behavior can be acceptable considering that some studies indicate higher tree susceptibility to form $\mathrm{CW}$ in the most internal zone of the trunk (Uprichard 1971, Bertaus and Holmbom 2004) while others, show more CW in the external growth ring (Harris 1977, Nicholls 1982).

The differences in alpha-cellulose content were significant only when the factor type of CW versus OW was compared (Table 4). This result agrees with the information available for $\mathrm{CW}$, showing that CW contains $20 \%$ to $25 \%$ less cellulose and it is also less crystalline (Timell 1982). The differences in alpha-cellulose content between both sites were apparent different with $\mathrm{p}=0.0609$. Thus, this result agrees with reports showing that alpha-cellulose yield has a great variability among trees from the same stand but their differences are not significant (Zobel et al. 1960). The alpha-cellulose differences between juvenile and mature wood obtained in the present study, were apparent significant with $\mathrm{p}=0.0589$. This result agrees with reports for Pinus radiata growing in Chile thus, indicating that alpha-cellulose differences were not age dependant (Paz y Ceballo 1965).

Pentose content in juvenile and mature wood turned out to be greater in $\mathrm{CW}$ than in OW. The statistic analysis showed that the differences between juvenile and mature wood, were statistically significant (Table 4). Pentose differences between juvenile and mature wood agreed with the decrease of pentose from the pith to the bark reported for Pinus radiata (Harwood 1971, Uprichard 1980, Uprichard and Lloyd 1980) There is about 4 to $8 \%$ more xyloses in juvenile than in mature Pinus radiata wood The arabinoses content wich is at a smaller percentage, also showed a reduction from $2 \%$ to $1 \%$, with age. Thus, a higher proportion of pentose in Pinus radiata has been found in juvenile wood (Harwood 1971, Berrocal et al. 2004).

In this study, the extractives' differences between CW and OW were moderate significant and do not agree with the results reported by Timell (1982). In the case of Pinus taeda wood there were no significant differences between mild CW and normal wood. Only moderate differences between severe CW and normal wood are shown (Shelbourne and Ritchie 1968). In our study, this extractive result suggests that $\mathrm{CW}$ could be more similar to severe than to mild $\mathrm{CW}$.

Moderate differences in the extractive percentages between juvenile and mature wood were found. (Table 4). This result agrees with those reported for Pinus radiata growing in Chile, showing that the percentage of ethanol-toluene is reduced between 4.7 to $1.7 \%$ from 1 to 20 years, and then increased up to 2.7, until 30 years, (Berrocal et al. 2004). It must be kept in mind that Pinus radiata extractives are generally near to $0.4 \%$ of the dry weight and that they depend on the heartwood degree (Uprichard and Lloyd 1980). In spite of the reduced extractive values in Pinus radiata wood, the differences found in trees from both sites, were statistically significant. 
The differences in holocellulose were no different when comparing CW and OW, and when comparing both sites' trees. As already mentioned, the results obtained were not statistically significant between those factors.

The ash values between $0.219 \%$ to $0.373 \%$, were smaller than expected according to the value $(0.46 \%)$ reported for Chilean Pinus radiata, with a high proportion of calcium content (Mancilla et al. 1991). The ash content differences were not statistically significant. The factors site, type of wood and age of the wood did not affect the ashes content (Table 4)

\section{CONCLUSIONS}

- The compression wood showed higher basic density and lignin proportion. The levels of those indicate that this $\mathrm{CW}$ corresponds to mild degree.

- The differences between $\mathrm{CW}$ and $\mathrm{OW}$ were significant for the proportion of lignin, the percentage of alpha-cellulose.

- The wood differences between both studied sites were significant for density and ethanol-toluene extractives.

- The results compared with those reported elsewhere, have been considered as the bases to assume that the leaning tree contained $\mathrm{CW}$ that would correspond to mild degree.

- Although these results can only be indicative, they allow a broad use at the industrial level, for example as preliminary log selection or as a basis for improving the productivity in sawmills and pulp mills.

\section{ACKNOWLEDGEMENTS}

Authors thank to Basic Research Committee from CMPC Celulosa, Laja, Chile, for their financial support. Thanks also to Professor Roger KEEY and Dr. Dave COWN for their valuable assistance.

\section{REFERENCES}

Altaner, C.; Hapca, A.; Knox, J.; Jarvis. 2007. Detection of beta-1-4-galactan in compression wood of Sitka spruce (Picea sitchensis (Bong.) Carriere) by immune fluorescence. Holzforschung 61(3):311-316.

American Society for Testing and Materials. 1984. Standard Test Method for Alpha-Cellulose in Wood: 346-348. ANSI/ASTM D 1103-60.

Akbulut, T.; Ayrilmis, N. 2006. Effect of compression wood on surface roughness and surface absorption of medium density fiberboard. Silva Fennica 40(1):161-167.

Ban, W.; Mancosky, D.; Lucia, L. 2004. Evaluation of the pulping response of juvenile and mature black spruce compression wood. Cellulose Chemistry and Technology 38(1-2): 79-85.

Berrocal, A.; Baeza, J.; Rodriguez, J.; Espinosa, M.; Freer, J. 2004. Effect of tree age on variation of Pinus radiata D.DON chemical composition. J. Chil. Chem. Soc. 49(3):251-256. 
Bland, D. 1958. The chemistry of reaction wood Part III: The milled wood lignins of Eucalyptus goniacalyx and Pinus radiata. Holzforschung 15(4):102-106.

Bertaus, F.; Holmbom, B. 2004. Chemical composition of earlywod and latewoods in Noway spruce heartwood, sapwood and transition wood. Wood Sci. Technol. 38: 245-256.

Burdon, R. 1975. Compression wood in Pinus radiata on four different sites. New Zealand Journal of Forestry Science 5(2):152-164

Cown, D.J.; McConchie, D.L.; Young, G.D. 1991. Radiata pine. Wood properties survey. FRI. Bulletin $\mathrm{N}^{\circ} 50,48 \mathrm{p}$.

Davis, C.; Carrington, C.; Sun Z. 2002. The influence of compression wood on the drying curves of Pinus radiata dried in dehumidifier conditions. Drying Technology 20 (10): 2005-2026

Delmastro, R.; Diaz-vaz, J.E.; Schlatter, J. 1982. Variabilidad de las características hereditarias del Pinus radiata (D. Don) Documento de Trabajo N 43 CONAF/PNUD/FAO. Santiago de Chile 89 pp.

Diaz-vaz, J.E. 1985. Duraminización de Pinus radiata creciendo en Chile. In: Pinus radiata investigación en Chile 162-177 pp.

Diaz-vaz, J.E.; Fernandez, A.; Valenzuela, L.; Torres, M. 2007. Madera de compresión en Pinus radiata D.Don: I Características anatómicas. Maderas. Ciencia y tecnología 9(1):29-43.

Donaldson, L.; Grace, J.; Downes, G. 2004. Within-tree variation in anatomical properties of compression wood in radiata pine. IAWA Journal 25(3):253-271.

Donaldson, L.; Turner, J. 2001. The influence of compression wood and microfibril angle on the occurrence of distortion in window frames made from radiata pine. Holz als Roh-und Werkstoff 59:163.168.

Du Torr, A. 1963. A study of the influence of compression wood on the warping of Pinus radiata D. Don timber. S. Afr.For.J. 44:11-15.

Haas, H.; Schoch, W.; Ströle, U. 1955. Herstellung von Skelettsubstanzen mit Peressigsäure. Das Papier 9(19-29): 469-475

Harris, M. 1977. Shrinkage and density of radiata pine compression wood in relations to its anatomy and mode of formation. New Zealand Journal of Forestry Science 7(1):91-106

Hannrup, B.; Danell, O.; Ekberg, L.; Moell. M. 2001. Relationships between wood density and tracheid dimensions in Pinus sylvestris L. Wood and Fiber Science 33(2):173-181.

Harwood, V. 1971. Variation in carbohydrate analyses in relation to wood age in Pinus radiata Holzforschung 25(3):73-77.

Haygreen, J., Bowyer, L. 1996. Forest products and wood science. An introduction. Third Edition, Iowa State University Press, USA.

Mancilla, H.; García, R.; Durán, H.; Urzúa, S. 1991. Chemical characterization of Chilean hardwoods. Wood Sci. Technol. 25: 145-149. 
Mayr, S.; Cochard, H. 2003. A new method for vulnerability analysis of small xylem areas reveals that compression wood of Norway spruce has lower hydraulic safety than opposite wood. Plant, Cell and Environment 26: 1365-1371.

Morales, E. 2005. Diseño experimental a través del análisis de varianza y modelo de regresión lineal. Ed. Carouna. Santiago, Chile 248 p.

Nicholls, J. 1982. Wind action, leaning trees and compression wood in Pinus radiata D.Don. Aust. For. Res.12:75-92.

Paz, J.; Ceballo, M. 1965. Contribución al estudio de la composición química orgánica del pino insigne. Actas de la reunión sobre investigación en productos forestales Instituto forestal. Informe técnico $\mathrm{N}^{\circ}$ 21. Santiago Chile. pp 94-98.

Raymond, C.; Joe, B. 2007. Patterns of basic density variation for Pinus radiata growth in south-west slopes region of New South Wales, Australia. New Zealand Journal of Forestry Science 37(1):81-95

Rivas, C. 1982. Determinación de madera juvenil en Pinus radiata D.Don. Tesis Ingeniería Forestal.Universidad Austral de Chile. 76p.

Roffael, E.; Essiamah, S.; Diaz-vaz, J.E.; Schneider, T.; Dix, B. 2005. Untersuchungen über den Einfluß von Reaktionsholz (Druckholz) und Normalholz der Fichte auf die Eigenschaften von mitteldichten Faserplatten (MDF). Forstarchiv (76): 206-214.

Shelbourne, C.; Ritchie, K. 1968. Relationships between degree of compression wood development and specific gravity and tracheid characteristics in Loblolly pine. Holzforschung 22(6):185-190.

Shelbourne, C.; Zobel, B.; Stonecypher, R. 1969. The inheritance of compression wood and its genetic and phenotypic correlations with six others traits in five-year-old Loblolly pine. Silvae Genetica 18:43-47.

Spicer, R.; Gartner, B. 1998. Hydraulic properties of Douglas-fir (Pseudotsuga menziesii) branches and branch halves with reference to compression wood. Tree Physiology 18:777-784.

Takabe, K.; Miyauchi, T.; Fukazawa, K. 1992. Cell wall formation of compression wood in Todo-fir (Abies sacharinensis) I. Depositions of polysaccharides. IAWA Bulletin n.s. 13(3):283-296.

TAPPI. 1984. Pentosans in Wood and Pulp. T 223 om 84. Standard Methods of the Technical Association of the Pulp and Paper Industry, New York, USA.

TAPPI. 1985. Ashes in Wood, Pulp, Paper and Paperboard: Combustion at 525 Degrees C. T 211 om 85. Standard Methods of the Technical Association of the Pulp and Paper Industry, New York, USA.

TAPPI. 1988a. Solvent Extractives of Wood and Pulp. T 204 om 88. Standard Methods of the Technical Association of the Pulp and Paper Industry, New York, USA.

TAPPI. 1988b. Acid-Insoluble Lignin in Wood and Pulp. T 222 om 88. Standard Methods of the Technical Association of the Pulp and Paper Industry, New York, USA. 
TAPPI. 1988c. Peparation of Wood for Chemical Analysis . T 264 om 88. Standard Methods of the Technical Association of the Pulp and Paper Industry, New York, USA.

Timell, T. 1982. Recent progress in the chemistry and topochemistry of compression wood. Wood Sci.Technol.16:83-122.

Timell, T. 1986. Compression wood in gymnosperms. Vol. 1-3, Springer-Verlag, Berlin 2150 p.

Uprichard, J. 1971. Cellulose and lignin content in Pinus radiata D.Don. Within-tree variation in chemical composition, density, and tracheid length. Holzforschung 5(4):97-105.

Uprichard, J.; Lloyd, J. 1980. Influence of the age on the chemical composition of radiata pine. New Zealand Journal of Forestry Science 10(3):551-557.

Uprichard, J. 1980. Effects of wood age on the papermaking properties of radiata pine kraft pulps. New Zealand Journal of Forestry Science 10(3): 558-576.

Warensjö, M.; Rune, G. 2004. Stem straightness and compression wood in a 22-year-old stand of container-grown Scots pine trees. Silva Fennica 38(2):143-153.

Yoshizawa, N.; Satoh, I.; Yokota, S.; Idei, T. 1992. Response of differentiating tracheids to stem inclination in young trees of Taxus cuspidata. IAWA Bulletin n.s. 13(2):187-194.

Zobel, B.; Thorbjornsen, E.; Henson, F. 1960. Geographic, site and individual tree variation in wood properties of Loblolly pine. Silvae Genetica 9:149-158. 
